\title{
INTER-MARKET AND SEASONAL VARIATION IN PRICES: AN APPRAISAL OF MAIZE MARKETING IN KWARA STATE
}

\author{
Ayinde, O.E. and Idris A. O. \\ Department of Agricultural Economics and Farm Management, University of Ilorin,Ilorin \\ opeayinde@yahoo.com
}

\begin{abstract}
This study investigated inter-market and seasonal variation in prices of maize in Kwara State. Secondary time series data on average monthly retail price of maize in urban and rural markets between 1998 and 2003 were used for the study. Primary data on the average storage cost of maize and the average selling price of maize for 2004 were also used for the study. The study described the seasonal pattern of maize, examined its seasonal price rise and analyzed the inter-market variation in prices of maize in the study area.

The study revealed that the seasonal price rise exceeds storage cost but the difference is minimal. The effect of kilometer separation between market- pairs on their Price difference is significant $(p<0.05)$. Thus, if storage cost should be reduced the intermarket price variation will be reduced while transportation cost should also be reduced to facilitate the movement of food commodities between markets.
\end{abstract}

Keywords: Inter-market, Price difference, Seasonal, Variation, and Maize.

\section{INTRODUCTION}

The ability of the marketing system to allocate grain over space and time has been a serious problem in agricultural marketing. Higgs et al (1981) observed that farmers are in business to sell their farm products at a fair returns or profit. CBN (2001), while commenting on post-harvest pricing and marketing, suggested that agriculture, like any other private enterprise, is propelled by entrepreneurs who are motivated by profits from their investments and entrepreneurship. Therefore, in order to ensure maximum returns, farmers must make his production decisions considering the most favourable place, time and form in which his product could be marketed. Consequently, prices of agricultural products vary from month to month and even from day to day. Prices also differ between various grades of a product and also differ between alternative markets. Having realized fact that prices varies considerably between different market locations and seasons of the year, it is therefore relevant to examine the reasons that may be responsible for such variations and to equally measure the extent of such price differences between places and time.

Geographical barriers separate agricultural commodities and the consumers of such commodities. Hence, the need to develop a marketing system that will connect the areas of production and consumption of agricultural products becomes very vital. At one end of the marketing system are the farmers who are the producers of agricultural crops while at the other end of the system are the consumers. The middlemen, however, occupy a strategic position in between the producers and the consumers. They facilitate the movement of agricultural commodities from the producers 
to the consumers of such commodities. Therefore, the middlemen perform several functions which include the effort to satisfy the wishes of the consumers with respect to space, form and time (Ejiga, 1988).

Apart from the separation of the areas of surpluses, and deficits by geographical barriers, Ejiga (1988) affirms that there is a lack of specialization in the production of agricultural commodities including maize consequently, there is in lack of concentration of supply, with only small surpluses available for sale at the end of the farming season. Meadows (2004) asserted that this low supply at the end of the farming season is passed on to the public at relatively high prices, and identifies it as one of the factors that militates against food security in Nigeria.

However, looking at the nature of agricultural supply, most farm products will require the addition of some of the marketing services performed by the middlemen before they can satisfy the wishes of the consumers in form, time and place. These services may be in the form of grading, packaging, storage and further processing. Thus they must be performed at some degree prior to the time of final consumption.

Therefore, the product in demand by the consumer at the retail level is a different product from that which is available at the farm. This difference may be attributed to time, place or the form that the products are. The difference between the price at farm-gate and the price in the market place during the year represents the payment to the owner of the grain storage facility and to those persons who assume the risks of price change (Ihimodu, 2003). Furthermore, the market intermediaries add value to the grain in distribution, and thus the services involved labour, time and capital which costs the farmers and consumers some money. The costs are been borne by the middlemen who are often alleged of being exploiting the farmers and the consumers. This study therefore focuses on the inter-market and seasonal variation in the price of maize in Kwara State with the specific objectives of describing of the inter-market and seasonal price pattern of maize and examining the seasonal price rise of maize in the study area.

Maize has been reported to have its wide utilization as a source of energy in the nutrition of human beings and livestock (Anon 1991). Maize is also an important food crop in Nigeria due to its high yield potential, storability and diversity of uses (FMANR 2001, Ajao, 2001). The production cycle of maize also allows for seasonal price behaviour. The dichotomous nature of the area of surplus and deficit of maize supply in Nigeria permit a study of this nature (Afolami, 2000). Maisamari (2002) declared that widespread interregional and inter-seasonal variations in prices tend to hamper adequate planning of farming, industrial operations and output expansion plans. (Flaskerud and Johnson 2000) emphasized that seasonal price patterns can be used as a guide for developing a marketing plan when they are examined along with supply, demand, information and other marketing concepts. Hence, this study on the marketing of maize in relation to the inter-market and seasonal price differences is appropriate and important. Findings from this study will therefore go a long way in enhancing maize marketing in the state. 


\section{METHODOLOGY}

This study was carried out in Kwara State of Nigeria which consists of sixteen Local Government Areas. Two of them are urban while the remaining fourteen are rural. In the urban Local Government Areas Oja -Oba market was purposefully selected being the central market in the State capital. Four Local Government Areas out of the fourteen rural Local Government Areas were randomly selected. Furthermore, the central market of each of the four randomly selected Local Government Areas was selected. In each of the selected central markets, twenty maize wholesalers were randomly selected.

Primary and secondary data were used for the study. The primary data were collected by the use of interview schedule to retrieve information on the storage cost, transport cost and sales of maize from randomly selected maize wholesalers. A total of one hundred questionnaires were administered but only eighty-two were found useful and analyzed. A secondary time-series data on average monthly retail price of maize in Kwara State and kilometre separation of the market - pairs was also used for the study.

The methods of data analysis used include descriptive statistics, Price Index number and regression analysis. The descriptive statistics used to describe the Inter-market and seasonal price pattern of maize in the study area include: averages, tables and graphs.

The Price index number was used to examine the seasonal price rise of maize. This is expressed as:

Monthly price indices $=\frac{\sum I_{m}}{n}$

Where, $\quad I_{m}=$ Monthly price index number

$$
\begin{aligned}
I_{m}= & \frac{\text { Average Monthly Price }}{\text { Average Annual Price of year } \mathrm{t}} \\
\mathrm{n}= & \text { number of years covered by the data } \\
\mathrm{t}= & \text { the particular year considered. }
\end{aligned}
$$

Total rise in seasonal price was obtained by subtracting month with highest index number from month with lowest index number.

The regression model used to analyze the seasonal variation in prices of maize following Afolami, (2000).

$$
\mathrm{P}_{\mathrm{t}}=\propto+\beta \mathrm{T}+\mathrm{U}_{\mathrm{t}}
$$

Where $\mathrm{P}_{\mathrm{t}}=$ Price per kg of maize at time $\mathrm{t}$,

$\mathrm{T}=$ trend variable for months, which was serially numbered as $1,2,3, \ldots$ starting from the month with the lowest index number.

$\propto$ and $\beta$ are the intercept and slope parameter of the model.

$\mathrm{U}=$ Error term.

Storage costs per ton/month for maize was estimated from the primary data collected. The average storage costs obtained from the five selected local 
government areas of the state was compared with the price rise per month, estimated from equation (1).

The element of storage costs in N/ton considered were: rentage on storage facilities; cost of preserving commodity; loss due to pest, disease and shrinkage; loss of handling and cost of sack used for storing maize.

The inter-market variation in prices was analyzed by using the regression model in equation (2).

$$
\mathrm{PD}_{\mathrm{ij}}=\mathrm{a}+\mathrm{bK}_{\mathrm{ij}}+\mathrm{U}
$$

Where $\mathrm{PD}_{\mathrm{ij}}$ is the price difference between any two markets (naira per kilogram)

$a$ and $b$ are the intercept and slope parameter respectively,

$\mathrm{U}=$ error term

It was assumed that the price difference between any two markets will be determined by the kilometer separation of the market - locations. Therefore, price difference between any two market places $\mathrm{PD}_{\mathrm{ij}}(\mathrm{N} /$ ton) was regressed on the kilometer separation of the market poor $\left(\mathrm{K}_{\mathrm{ij}}\right)$ for each year.

\section{RESULTS AND DISCUSSION}

It was revealed from the study that the percentage of male that engaged in maize selling in the study area is $37.8 \%$ while that of female is $62.2 \%$, thus revealing a higher percentage of female maize trader. This may be due to the fact that selling maize education and people with formal education are just there to help their parents or relatives in the market.

Table 1: $\quad$ MODE OF TRANSPORTATION OF MAIZE

\begin{tabular}{|c|c|c|}
\hline $\begin{array}{l}\text { MODE } \\
\text { OFTRANSPORTATION }\end{array}$ & NO OF RESPONDENTS & PERCENTAGE \\
\hline Truck & 69 & 85.4 \\
\hline Taxi & 5 & 6.1 \\
\hline Personal Vehicle & 6 & 7.3 \\
\hline Hire pick-up & 2 & 2.4 \\
\hline Total & 82 & 100 \\
\hline
\end{tabular}

Source: Field survey 2004

Majority of the maize wholesalers uses truck to convey their commodities from the point of purchase to the market place (Table 1). This may be due to the fact that wholesalers may want to utilize economics of scale by joining their supply together to transports by truck. 
Majority of the respondents obtained their supply from the local markets while very few obtain theirs from their own farms (Table 2). The prices of maize and other commodities may therefore be are cheaper at the local markets.

Table 2: $\quad$ SOURCES OF SUPPLY BY THE RESPONDENTS

\begin{tabular}{|c|c|c|}
\hline SOURCE OF SUPPLY & NO OF RESPONDENTS & PERCENTAGE \\
\hline Local market & 50 & 60 \\
\hline Own farm & 2 & 2.4 \\
\hline Farm Gate & 10 & 12.2 \\
\hline Cooperative farm & 5 & 6.19 \\
\hline Others & 15 & 18.3 \\
\hline Total & 82 & 100 \\
\hline
\end{tabular}

Source: Field survey 2004

Table 3: $\quad$ MODE OF STORING MAIZE BY THE RESPONDENT

\begin{tabular}{|c|c|c|}
\hline MODE OF STORING & NO OF RESPONDENTS & PERCENTAGE \\
\hline Fertilizer bag & 65 & 73.2 \\
\hline Jute bag & 15 & 18.4 \\
\hline Bin & 2 & 2.4 \\
\hline Total & 82 & 100 \\
\hline
\end{tabular}

Source: Field survey 2004

Majority of the respondents (73.2\%) use fertilizer bags for their storage while only very few uses bin (Table3). This is because fertilizer bags are very cheap, economical and easy to apply chemical preservatives. 


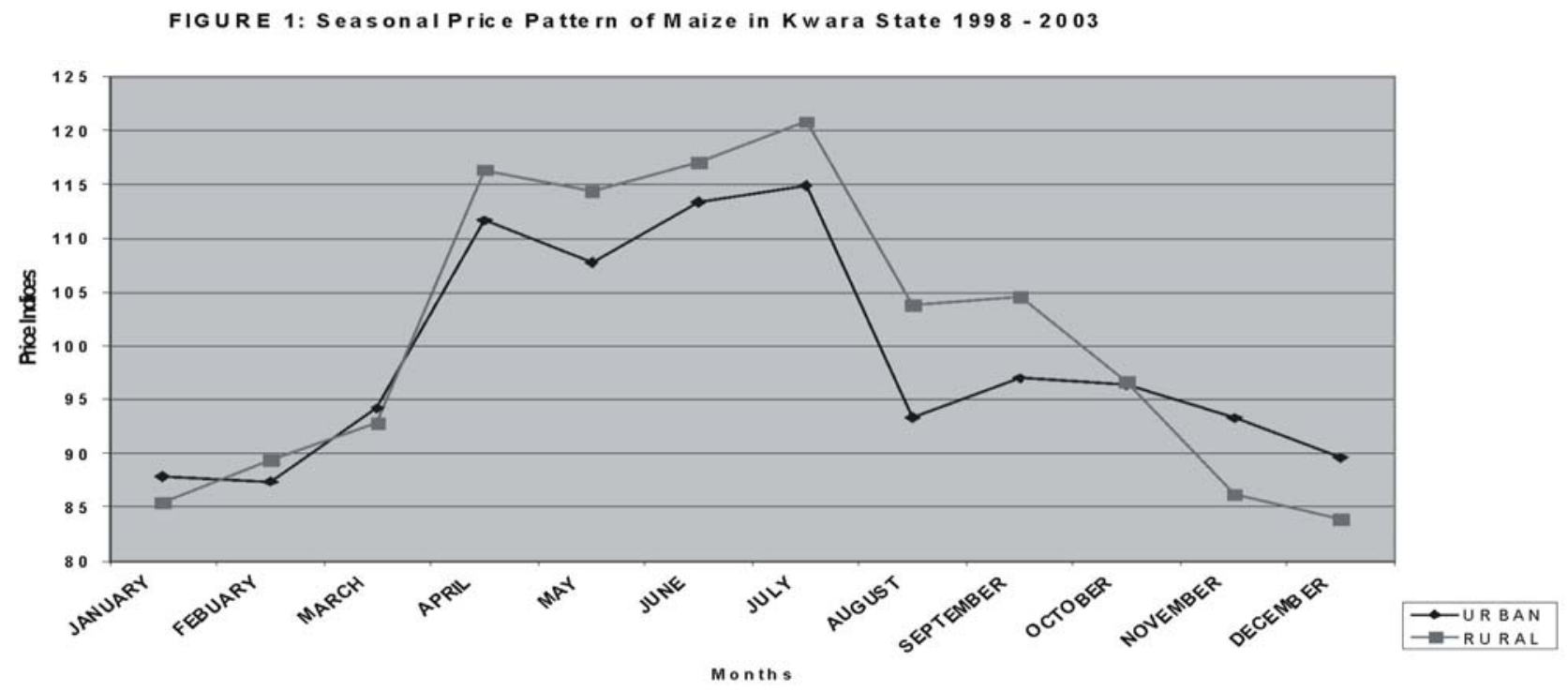

Fig. 1 shows the seasonal price pattern of maize in Kwara State. Maize price rises between April to July (Raining season), and starts falling from August to November with a slight rise in September before stablishing from November to February (Dry season) in both urban and rural markets in Kwara State. This is a clear indication that maize price exhibits high variability during seasons.

Table 4: $\quad$ Measure of seasonal movements in prices of maize in Kwara State 1998-2003

\begin{tabular}{|l|l|l|l|l|}
\hline $\begin{array}{l}\text { Market } \\
\text { Location }\end{array}$ & \multicolumn{2}{|l|}{ Seasonal Index } & $\begin{array}{l}\text { Total rise in } \\
\text { seasonal } \\
\text { price (\%) }\end{array}$ & $\begin{array}{l}\text { Average monthly rise } \\
\text { in seasonal price (\%) }\end{array}$ \\
\hline & High month & $\begin{array}{l}\text { Low } \\
\text { month }\end{array}$ & & \\
\hline Urban & July & Feb. & 27.03 & 5.46 \\
\hline Rural & July & Dec. & 36.97 & 5.28 \\
\hline
\end{tabular}

Source: Derived from appendix 1.

The average monthly price rises using index number approach are 5.46 and 5.28 for urban and rural market respectively (Table 4). The price index at its peak was found to be 114.9 and 120.9 in July for both Urban and Rural markets respectively. The price index was also at its lowest point in February with 87.4 for urban market and in December with 83.9 for rural markets (appendix 1). Consequently it might be possible to predict that maize is cheaper during dry season and specifically at the month of February for urban market and December for rural markets.

The regression equation of price at time $t$, on trend variable $(\mathrm{T})$, showed that all the regression lines were significant at five-percent level (table 5). Hence the intercept 
and slope parameters are significantly different from zero for all market locations during the period under review.

Table 5: Summary of Regression Results

\begin{tabular}{|c|c|c|c|c|}
\hline Year & Intercept & $\begin{array}{l}\text { Trend } \\
\text { Variable }\end{array}$ & $\mathrm{R}^{2}$ & Slope/Intercept \\
\hline $\begin{array}{l}1998 \\
\text { Urban } \\
\text { Rural }\end{array}$ & $\begin{array}{l}11.295^{*} \\
(22.696) \\
8.831^{*} \\
(10.114)\end{array}$ & $\begin{array}{l}1.519^{*} \\
(22.464) \\
1.408^{*} \\
(10.119)\end{array}$ & $\begin{array}{l}0.979 \\
0.934\end{array}$ & $\begin{array}{l}0.134 \\
0.159\end{array}$ \\
\hline $\begin{array}{l}1999 \\
\text { Urban } \\
\text { Rural }\end{array}$ & $\begin{array}{l}14.120^{*} \\
(39.676) \\
12.499 * \\
(26.530)\end{array}$ & $\begin{array}{l}0.482^{*} \\
(9.976) \\
0.486^{*} \\
(7.592) \\
\end{array}$ & $\begin{array}{l}0.909 \\
0.852\end{array}$ & $\begin{array}{l}0.034 \\
0.039\end{array}$ \\
\hline $\begin{array}{l}2000 \\
\text { Urban } \\
\text { Rural }\end{array}$ & $\begin{array}{l}15.051^{*} \\
(57.275) \\
12.993 * \\
(39.333)\end{array}$ & $\begin{array}{l}0.598 * \\
(16.741) \\
0.702 * \\
(15.636)\end{array}$ & $\begin{array}{l}0.966 \\
0.961\end{array}$ & $\begin{array}{l}0.039 \\
0.054\end{array}$ \\
\hline $\begin{array}{l}2001 \\
\text { Urban } \\
\text { Rural }\end{array}$ & $\begin{array}{l}21.501 * \\
(17.734) \\
16.702 * \\
(12.600)\end{array}$ & $\begin{array}{l}2.218^{*} \\
(9.667) \\
3.040^{*} \\
(16.882)\end{array}$ & $\begin{array}{l}0.903 \\
0.966\end{array}$ & $\begin{array}{l}0.103 \\
0.182\end{array}$ \\
\hline $\begin{array}{l}2002 \\
\text { Urban } \\
\text { Rural }\end{array}$ & $\begin{array}{l}35.412 * \\
(49.396) \\
26.264^{*} \\
(19.862)\end{array}$ & $\begin{array}{l}1.257^{*} \\
(12.900) \\
2.177^{*} \\
(12.116)\end{array}$ & $\begin{array}{l}0.943 \\
0.936\end{array}$ & $\begin{array}{l}0.035 \\
0.083\end{array}$ \\
\hline $\begin{array}{l}2003 \\
\text { Urban } \\
\text { Rural }\end{array}$ & $\begin{array}{l}22.263^{*} \\
(6.999) \\
23.631^{*} \\
(23.665)\end{array}$ & $\begin{array}{l}2.342 * \\
(5.422) \\
1.342 * \\
(9.889)\end{array}$ & $\begin{array}{l}0.746 \\
0.907\end{array}$ & $\begin{array}{l}0.105 \\
0.057\end{array}$ \\
\hline $\begin{array}{l}\text { Total } \\
\text { Urban } \\
\text { Rural } \\
\end{array}$ & $\begin{array}{l}119.64 \\
100.92 \\
\end{array}$ & $\begin{array}{l}8.42 \\
9.16 \\
\end{array}$ & $\begin{array}{l}5.446 \\
5.556 \\
\end{array}$ & $\begin{array}{l}0.450 \\
0.574 \\
\end{array}$ \\
\hline $\begin{array}{l}\text { Average } \\
\text { Urban } \\
\text { Rural }\end{array}$ & $\begin{array}{l}19.940 \\
16.820\end{array}$ & $\begin{array}{l}1.403 \\
1.526\end{array}$ & $\begin{array}{l}0.9077 \\
0.9260\end{array}$ & $\begin{array}{l}0.075 \\
0.096\end{array}$ \\
\hline
\end{tabular}


Using all the regression equations, the average intercept values for urban and rural markets are 19.940 and 16.82 respectively. While the average slope for urban and rural markets are 1.403 and 1.526 respectively. Also the slope to intercept ratios are 0.075 and 0.096 respectively. The intercept values indicate the average price of the commodity after adjustment has been made for the trend. The slope values give the price rise per kilogramme per month while the ratio of slope value to intercept value multiplied by 100 gives the percentage price rise over and above the average price for urban and rural markets respectively. Therefore, in summary the ratio of slope value to intercept value multiplied by 100 for urban and rural markets are 7.5 and 9.6 respectively and they represent the percentage price rise per month over and above the average prices for urban and rural markets.

However, given that maize price $\mathrm{Pt}$ in equation (1) is in naira $/ \mathrm{kg}$, the slope results of 1.403 and 1.526 for urban and rural markets translates to price rise of $\$ 1,403$ and 1,526 per ton respectively for urban and rural markets respectively. Thus the seasonal price rise of maize for urban and rural markets in naira per ton are $\$ 1,403$ and $\$ 1$, 526. Obviously from the study, the seasonal price rise for rural markets is greater than that of urban market. This may be because the rural suppliers may have disposed off their stocks and have to go back to urban centres for fresh supply.

Table 6: Average cost of storing one metric tone of maize Kwara State.

\begin{tabular}{|l|l|}
\hline Local Government Area & Average cost of storing ( metric tonnes) \\
\hline Oyun- Erinle market & 299.90 \\
\hline Irepodun- Omu-Aran market & 238.98 \\
\hline Ilorin- Oja-Oba market & 660.00 \\
\hline Offa- Offa market & 455.70 \\
\hline Ifelodun- Ganmo market & 459.41 \\
\hline Average storage cost in Kwara State & 411.69 \\
\end{tabular}

Source: Field Survey 2004

The average storage cost estimate of maize in Kwara State from table 6 is $¥ 411.69$ per ton while the seasonal price rise per ton for urban and rural market are $\$ 1,403$ and $¥ 1,526$ respectively. Therefore, a trader in urban and rural market will earn $¥ 991.31$ and $¥ 1,114.31$ per ton for urban and rural market respectively. Although estimate of the seasonal price rise per ton exceed the storage cost but the difference is still minimal. 
Table7: Summary of price difference between market pairs and their kilometre separation in Kwara State year .

\begin{tabular}{|l|l|l|l|l|}
\hline Year & Intercept & $\begin{array}{l}\text { Kilmetre } \\
\text { seperation }\end{array}$ & $\mathrm{R}^{2}$ & Adjusted $\mathrm{R}^{2}$ \\
\hline 2004 & $\begin{array}{l}-140.572^{*} \\
(-0.288)\end{array}$ & $\begin{array}{l}43.610^{*} \\
(3.260)\end{array}$ & 0.914 & 0.828 \\
\hline
\end{tabular}

Source: Field Survey 2004

Values in bracket are t-values

*significant at five percent level

The price difference between the market-pairs can be attributed to the kilometre separation between the market-pairs, since the slope of the regression line is significantly different from zero at five percent level (Table 7). The slope value of 43.610 in regression equation in table 7 indicates that if kilometre separation of market-pairs increases by one, price difference for maize between markets increases by $\$ 43.610$ per ton. This amount represents the returns to the traders that engage in inter-market buying and selling of maize and it includes transportation cost per ton per kilometre, cost of loading and unloading and lost in transit. This amount seems not too large, as when compared to the high cost of transportation, illegal fees collected on our major roads and the general risks involved in the movement of Agricultural commodities between one market to the other.

\section{CONCLUSION AND RECOMMENDATIONS}

The study found that the percentage monthly price rise for maize in urban and rural markets were 5.41 and 5.28 percent respectively using the index number approach while the corresponding values using the regression analysis are 7.5 and 9.6 percent respectively. The regression analysis revealed further that the average monthly price rises are 1.403 and 1.526 per kilogram for urban and rural markets. These translate to a price rise of $\$ 1,403$ and $\$ 1,526$ per tonne for urban and rural markets respectively.

The average storage cost in naira per tonne per month was obtained as N411.69 Seasonal price rise per tonne for maize minus the average storage cost in naira per tonne shows that the middlemen earns $\$ 991.31$ per tonne or $\$ 1,114.31$ per ton kilogram for urban and rural market respectively.

This amount exceeds the storage costs but this difference still minimal. The result of regression analysis showed that when kilometer increased by one, the price difference in Naira per kilogram between market-pairs over the period of study was \$43.610 per ton. This margin comprises of traders profit, transportation cost of maize, the cost of loading and unloading as well as commodity loss in transit. It is therefore concluded that there is inter-market and seasonal variation in prices of maize in the study area during the period of study.

Given the result of this study, the only way to reduce maize price over time and between market-pairs is through better and efficient maize storage system which will reduce storage cost, efficient market information to enable traders know when to store 
and the quantity to store. Inter-market price difference can also be reduced through better and efficient transportation system and the presence of other physical facilities.

There is therefore a strong need for Government to provide for more and better dissemination of market intelligence and information among the farmers and traders to improve knowledge, combat supply uncertainty and reduce risk associated with intermarket trade

Government should equally increase the physical facilities associated with storage facilities in the markets, feeder roads, and bridges linking rural areas to urban centres while social amenities should be provided in rural areas to reduce rural -urban migration.

The marketers should equally form cooperatives or association that can assist them in provision of physical facilities and better dissemination of market intelligence and information.

\section{REFERENCES}

Afolami, C.A. (2000): "Inter-temporal and spatial pricing efficiency for maize marketing in Nigeria". Journal for Agricultural Research (1)77-85.

Ajao, F.A. (2001). Effect of introgressing the su genes from the sweet corn (zea mays) on grain quality characteristics of three field corn varieties. Unpublished B. Agric project University of Ilorin.

Annon, J.O. (1991). "Maize Research Programme. Maize Quality and Utilization project" Annual Report International Institute of Tropical Agriculture Ibadan pp 1-10

Central Bank of Nigeria (CBN, 2001). Report of the first annual monetary policy conference, November.

Ejiga, N.O.O (1988). Pricing efficiency for cowpea northern Nigeria. Readings in Agricultural Marketing in T. O. Adekanye (Ed) Longman Nigeria Limited. Ibadan. pp.157-167

Flaskerud, G. and Johnson, D. (2000): "Seasonal rice patterns for crops". North Dakota state University of Extension Service publication - Ec-1012, November 1-10.

Federal Ministry of Agriculture and Natural Resources (F.M.A.N.R, 1999). Annual Report for 1999.

Higgs,C.P, W.Y. Ritson, and C.N Williams. (1981): Agricultural Mathematics. Interstate printers and publishers limited, London. 2 - 6.

Ihimodu,I.I.(2003): Marketing of Agricultural products and the Food security programme in Nigeria. "Paper presented at a workshop organised by the Nigerian Rural sociological Association", November. 25-28.

Maisamari, J. Y. (2002): Seasonal Price Variation. "Paper presented at the tenth annual conference of the central bank of Nigeria's Zonal Research Unit". Abuja, Nigeria. April 6th-8th.

Meadows, B. (2004): Current challenges in the food industry in Nigeria. "Paper presented at a workshop organized by the Nigerian Institute of Food Science and Technology". Lagos. 
Appendix 1: Monthly Price Index for Maize 1999 - 2003

\begin{tabular}{|c|c|c|c|c|c|c|c|c|c|c|c|c|c|c|}
\hline & \multicolumn{2}{|l|}{1998} & \multicolumn{2}{|l|}{1999} & \multicolumn{2}{|l|}{2000} & \multicolumn{2}{|c|}{2001} & \multicolumn{2}{|l|}{2002} & \multicolumn{2}{|l|}{2003} & \multicolumn{2}{|c|}{$\begin{array}{l}\text { Monthly Price } \\
\text { Indices }\end{array}$} \\
\hline & $\mathrm{U}$ & $\mathrm{R}$ & $\mathrm{U}$ & $\mathrm{R}$ & $\mathrm{U}$ & $\mathrm{R}$ & $\mathrm{U}$ & $\mathrm{R}$ & $\mathrm{U}$ & $\mathrm{R}$ & $\mathrm{U}$ & $\mathrm{R}$ & $\mathrm{U}$ & $\mathrm{R}$ \\
\hline Jan & 85.0 & 83.6 & 97.7 & 94.0 & 84.9 & 88.2 & 58.4 & 61.3 & 94.1 & 98.6 & $\begin{array}{l}107 . \\
0\end{array}$ & 86.8 & 87.9 & 85.4 \\
\hline Feb & 97.1 & $\begin{array}{l}113 . \\
3\end{array}$ & 86.9 & 95.8 & 78.7 & 78.7 & 77.4 & 63.1 & 83.8 & 89.5 & $\begin{array}{l}100 . \\
5\end{array}$ & 95.8 & 87.4 & 89.4 \\
\hline Mar & 91.0 & $\begin{array}{l}102 . \\
0\end{array}$ & 79.4 & 94.0 & 98.5 & 76.7 & 92.0 & 82.3 & $\begin{array}{l}105 . \\
7\end{array}$ & $\begin{array}{l}108 . \\
2\end{array}$ & 93.3 & 93.6 & 94.2 & 92.8 \\
\hline Apr & $\begin{array}{l}128 . \\
9\end{array}$ & $\begin{array}{l}118 . \\
7\end{array}$ & $\begin{array}{l}110 . \\
8\end{array}$ & $\begin{array}{l}115 . \\
2\end{array}$ & $\begin{array}{l}101 . \\
0\end{array}$ & $\begin{array}{l}103 . \\
4\end{array}$ & $\begin{array}{l}142 . \\
3\end{array}$ & $\begin{array}{l}135 . \\
8\end{array}$ & 82.6 & $\begin{array}{l}111 . \\
7\end{array}$ & $\begin{array}{l}104 . \\
7\end{array}$ & $\begin{array}{l}107 . \\
8\end{array}$ & $\begin{array}{l}111 . \\
7\end{array}$ & 116.4 \\
\hline May & 136. & $\begin{array}{l}150 . \\
8\end{array}$ & 98.5 & $\begin{array}{l}101 . \\
2\end{array}$ & $\begin{array}{l}105 . \\
6\end{array}$ & $\begin{array}{l}109 . \\
8\end{array}$ & 96.1 & 91.4 & $\begin{array}{l}103 . \\
1\end{array}$ & $\begin{array}{l}124 . \\
2\end{array}$ & $\begin{array}{l}106 . \\
9\end{array}$ & $\begin{array}{l}108 . \\
8\end{array}$ & $\begin{array}{l}107 . \\
8\end{array}$ & 114.4 \\
\hline Jun & $\begin{array}{l}123 . \\
2\end{array}$ & $\begin{array}{l}142 . \\
9\end{array}$ & $\begin{array}{l}115 . \\
9\end{array}$ & $\begin{array}{l}126 . \\
8\end{array}$ & 94.5 & 99.7 & $\begin{array}{l}117 . \\
5\end{array}$ & $\begin{array}{l}100 . \\
9\end{array}$ & $\begin{array}{l}120 . \\
0\end{array}$ & $\begin{array}{l}123 . \\
0\end{array}$ & $\begin{array}{l}109 . \\
0\end{array}$ & $\begin{array}{l}109 . \\
0\end{array}$ & $\begin{array}{l}113 . \\
4\end{array}$ & 117.1 \\
\hline Jul & 131. & $\begin{array}{l}122 . \\
7\end{array}$ & $\begin{array}{l}100 . \\
8\end{array}$ & $\begin{array}{l}110 . \\
8\end{array}$ & $\begin{array}{l}115 . \\
4\end{array}$ & $\begin{array}{l}125 . \\
4\end{array}$ & $\begin{array}{l}127 . \\
1\end{array}$ & $\begin{array}{l}137 . \\
1\end{array}$ & $\begin{array}{l}101 . \\
7\end{array}$ & $\begin{array}{l}107 . \\
7\end{array}$ & $\begin{array}{l}113 . \\
0\end{array}$ & $\begin{array}{l}119 . \\
5\end{array}$ & $\begin{array}{l}114 . \\
9\end{array}$ & 120.9 \\
\hline Aug & $\begin{array}{l}106 . \\
2\end{array}$ & 71.1 & $\begin{array}{l}100 . \\
5\end{array}$ & 96.9 & 99.5 & 96.9 & $\begin{array}{l}119 . \\
9\end{array}$ & $\begin{array}{l}125 . \\
2\end{array}$ & 93.8 & $\begin{array}{l}111 . \\
7\end{array}$ & 40.4 & $\begin{array}{l}121 . \\
1\end{array}$ & 93.4 & 103.8 \\
\hline Sep & 97.6 & 78.5 & 92.9 & $\begin{array}{l}101 . \\
4\end{array}$ & 91.3 & 99.1 & 86.2 & $\begin{array}{l}146 . \\
4\end{array}$ & 98.3 & 74.5 & $\begin{array}{l}115 . \\
8\end{array}$ & $\begin{array}{l}108 . \\
8\end{array}$ & 97.0 & 104.6 \\
\hline Oct & 57.3 & 78.5 & $\begin{array}{l}101 . \\
7\end{array}$ & 93.1 & $\begin{array}{l}110 . \\
1\end{array}$ & $\begin{array}{l}108 . \\
3\end{array}$ & 90.9 & 60.9 & $\begin{array}{l}109 . \\
3\end{array}$ & 74.5 & $\begin{array}{l}108 . \\
9\end{array}$ & $\begin{array}{l}109 . \\
0\end{array}$ & 96.4 & 96.7 \\
\hline Nov & 66.1 & 69.1 & $\begin{array}{l}114 . \\
2\end{array}$ & 81.3 & $\begin{array}{ll}117 . \\
5\end{array}$ & $\begin{array}{l}119 . \\
7\end{array}$ & 91.2 & 99.9 & 98.3 & 73.9 & 72.5 & 73.8 & 93.3 & 86.2 \\
\hline Dec & 78.1 & 72.8 & 100.4 & 92.3 & 102.7 & 94.5 & 92.1 & 95.2 & $\begin{array}{l}109.3 \\
\end{array}$ & 74.5 & 54.9 & 74.7 & 89.6 & 83.9 \\
\hline
\end{tabular}

Source: Calculated from secondary data on Average monthly Retail Price of Maize in

Kwara State 1998-2003

$\mathrm{U}=$ urban market

$\mathrm{R}=$ rural market 